\title{
A BLACK WOMAN CHARACTER'S TRAUMA IN RACIST SOCIETY: A THOROUGH READING ON FAULKNER'S "THAT EVENING SUN"
}

\author{
Sri Sumaryani \\ Yogyakarta State University
}

\begin{abstract}
This paper discusses a black woman character named Nancy in Faulkner's "That Evening Sun" who experiences trauma as the accumulation of her constant fear. The analysis is conducted by using Fanon's theory of psychological trauma in colonial society. The researcher used descriptivequalitative method as it is a qualitative research in which data are nonnumeric. The analysis examines Nancy's unconsciousness resulted in a trauma. It also highlights Faulkner's technique to compare fear experienced by Blacks and Whites.

Based on the analysis, Nancy's fear is sourced from her husband's harsh treatments because she is pregnant with a white man's child. Her husband's violent treatments are the manifestation of his disappointment and anger towards his racist surroundings. Nancy's acute fear is worsened by her surroundings' treatment that mostly consist of white Southerners and are apathetic towards her fear. The crippling fear accumulates into trauma. Faulkner's method to contrast the fear experienced by Whites and Blacks are effective to show that the level of fear felt by Blacks is greater than that of Whites.
\end{abstract}

Key words: trauma, fear, racist

\section{INTRODUCTION}

\section{Racism in the Southern United Sates}

The history of the United States of America cannot be separated from racism issue. The struggle to gain independence from Britain in the $18^{\text {th }}$ century led to the freedom of the land and self from colonization. However, the freedom was not 
possessed by all people. The independence was merely owned by Whites or most notably known as the WASP (White Anglo-Saxon Protestants), a group of people whose descendants were originally from Europe. Blacks from African descendants did not have the same felicity as the first group. Their access to some basic rights like economics and life was limited prior and even long after the independence was declared in 1776. Slavery which is regarded as a firm institution hampered Blacks from gaining the proper living. The difference of treatments between these two races irritated some Whites who concerned with Blacks and craved for the same treatments. The demand put the heat on the defenders of the slavery. It reached the peak on the Civil War that lasted from 1861-1865. The era noted the simmering tension between the Northern and Southern United States (McNeese, 2010: 24). The first one opposed slavery while the second one was consistent in maintaining it.

The division of arguments between the two regions upon slavery was not solely driven by human rights principles. It was more on economic motivations. The Northern depended on industrial based economy while their brothers in the South remained entirely rural. Southerners relied on their life on agriculture. (McPherson, 1988:354). The vast plantation of cotton and tobacco were the main products and this rural industry required large numbers of slaves. Slaves were cheap labors because they were treated like goods. Slave trade was considered usual at that time. Moreover, slaves' descendents followed the status of their parents. The morality and economic competition motivated the confrontation that lasted for five years in the Civil War. Apart from the war, the lives of Blacks in the South as the slavery based region did not technically change much even after the $13^{\text {th }}$ Amendment which banned slavery practice was imposed in 1865 .

Slavery was not a peculiar practice in the South. It was a strong institution and inseparable from the life of the Southerners. Through centuries, slavery remained as a rigid social institution which classified the life of Whites and Blacks as masters and slaves. Slavery is a perfect tool to implement racism because the lives of Blacks were dependent on their masters and the dependency created the power to rule Blacks as the more inferior group. It goes accordingly with the prominent principal of racism which is the doctrine about the division of population's category based on physical differences. The emergence of superiority feeling as a consequence of racism practice will be followed by the inception of inferior group. Superiority demands inferiority as the antithesis. The classification of population based on mere appearance is the basic principal to legalize the 
practice of slavery. Therefore, it is reasonable that the $13^{\text {th }}$ Amendment caused no significant change towards the life of Blacks. Officially they were free, but the treatment from Whites was not equitable.

The South plantation society were segregated society. The segregated system that evolved after the Civil War was strengthened by the existence of Jim Crow Laws (Smith, 2002: 77). The purpose of which was to regulate all dealings between Blacks and Whites so that the difference between Blacks and Whites status were consistently shown and publicly confirmed (Lowe, 2005: 41). The Southerners consisted not only Blacks, but also Whites. Living under the conduct of racist Jim Crow Laws, the harsh living endured by Blacks in the South was no less than Whites. Segregation is the basic aim of the Jim Crow Laws. Basically, the white Southerners used Jim Crow Laws as a medium to manage the threat of racial intermixing associated with wider circulation of people throughout the South (Matthews, 2009: 154). This meant frustration for the Blacks because literally their lives did not change that much than the previous period.

Living under the Jim Crow Laws conduct also made Blacks suffer and the suffering often led to psychological effect which was traumatic experience. Whites also faced this experience, mostly when the depression affected their economy. They experienced loss, both in economy as well as pride because their brothers in the North got the upper hand. However, it is important to note that this group's traumatic experiences are considered secondary and slight compared to the experiences of Blacks in the colonial period (Matthews, 2009: 100).

The segregated lives and treatments caused traumatic experiences to some of the Blacks. They felt that they were not able to endure uncomfortable environment. Some Blacks refused to follow the etiquette and it usually became the news on the local newspaper (Ayers, 1998: 89). The misbehaving of Blacks added their images as savage characters and Whites, particularly women and girls were raised by a concept that Blacks, especially men, were living threats to their lives. Blacks were also afraid of lynching if they were suspected doing unpleasant things like crime yet most lynchings were executed because Whites felt insecure about Blacks' existence. The lives of both races in the South were under appalling atmosphere. However, most of all, Blacks had weaker condition because their status as slaves in the past was justified by Whites as a reason to marginalize Blacks at that present time. Therefore, Blacks suffered more unfairness and constant fear which often led to trauma. 
The issue of the lives of Blacks in the Southern community has long been famously correlated with William Faulkner's works. He brought the story of his homeland, Mississippi, in most of his writings. The famous region Yoknapatawpha in Jefferson County was the name he coined to mark the foremost place where most of his characters were based. "That Evening Sun" is a genius portrayal about the life of a black woman named Nancy working as a servant for a Southern white family. She was occupied by her crippling fear that his husband, Jesus, would come and murdered him because she was pregnant with a white man's baby. Moreover, it also depicted the attitudes of white people, represented by Compson's family, to react upon their servant's fear.

Throughout the story, the readers dealt a lot with Nancy's struggle to overcome the fear. She begged to the Compson's children to accompany her during a night. The naïve children responded the plead by teasing each other and showed no interest in Nancy's fear. Told by Quentin, the central character in most of Faulkner's work, the short story was Quentin's own experience fifteen years before. He was one of the Compson's kids who was apathetic towards his female servant's dread of being killed by her husband.

The main theme that needs to be pointed out is the overcoming fear by a black woman which means nothing for the Whites. The accumulation of fear leads to the feeling of unconsciousness and trauma because Nancy starts to hallucinate things that actually never happen.

\section{METHODS OF THE RESEARCH}

The writing aims to analyze the unconsciousness of Nancy as the result of traumatic experiences dealing with the fear and the comparison of fear experienced by black and white characters in the story. The researcher used Frantz Fanon's theory of psychological trauma in the colonial society taken from his book entitled Black Skin, White Masks which discusses racial differences in colonial and postcolonial societies. The researcher used a descriptive-qualitative method as it is a qualitative research of which data are nonnumeric.

\section{FANON'S THEORY OF PSYCHOLOGICAL TRAUMA}

Black Skin, White Masks is a series of Fanon's personal and racial traumatic experiences with his surroundings, particularly when he served as a soldier for the 
French military and a psychiatric. The book explains the psychology of colonialism. In the realm of colonial life, inferior complex is planted by the colonized through the mechanism of racism. Therefore, it also studies the minds of the marginalized as the proof of the effect of colonization. Those who become the objects of study in the book are groups who experienced direct racism, including the author.

In Robert Jay Lifton's terms, traumas are near-death experiences in which people lose touch with links to other humans, and to the sense of community or group so basic to human identity. Trauma is usually experienced in the form of images in a flashback or a nightmare, accompanied by painful bodily sensations (Lifton in Kaplan, 1999: 147). The feeling makes the owner of the body feels unconscious. It is because the consciousness is inferior to the traumatic experience. In the colonial and postcolonial societies, traumas are caused by the racist treatments and mostly experienced by the colonized. This is how Fanon explains the feeling of trauma:

On that day, completely dislocated, unable to be abroad with the Other, the white man, who unmercifully imprisoned me, I took myself far off from my own presence, far indeed, and made myself an object. What else could it be for me but an amputation, an excision, a hemorrhage that splattered my whole body with black blood? (Fanon, 2008: 85).

For white men as the colonized, Blacks are merely objects. The feeling of inferiority is accumulated and makes Blacks insecure because they feel that they live under the control and the dictate of the Whites. Outrage is not an enough release to endure the lives in the colonial societies. When Blacks undergo the unfortunate lives, slowly their consciousness loses to the suffering, either mental or physical, which leads to the collapse of self-control and creates trauma. When people experience trauma, they lose their selves and their minds are occupied by the fear that has been already accumulated. The fact is Blacks' degradation mentally and physically due to the racial injustice. Fanon adds that in dealing with the white world, Blacks must have strong psychic structure. If their psychic structure is weak, they will experience the collapse of the ego. The result is they will transfer into somebody else and stop behaving as an actional person (Fanon, 2008: 119). They are living under the shadow of the white world.

The racial injustice is sourced from the racial prejudices maintained by Whites. The racial prejudices are a list of unreasonable opinions made as if as facts 
to legalize the treatments of the colonizer to the colonized. The racial prejudices are carried out for a long period of time and transform into ideology which later on become harder to eradicate. However, Blacks do not have enough bargaining position to challenge this ideology, thus it remains as it is. Fanon illustrate the condition as the following;

I had rationalized the world and the world had rejected me on the basis of color prejudice. Since no agreement was possible on the level of reason, I threw myself back toward unreason. It was up to the white man to be more irrational than I. Out of the necessities of my struggle I had chosen the method of regression, but the fact remained that it was an unfamiliar weapon; here I am at home; I am made of the irrational; I wade in the irrational (Fanon, 2008:93).

The social and psychological marginalization of the Blacks by the colonized is able to make Blacks desire to change themselves into Whites. The desire to change into Whites is the psychological proof of being inferior. So strong is the influence of white culture as the dominant power, the dream to become Whites in the mind of the Blacks is prominent. In one circumstance, Fanon's meeting with his patient reveals the fact that due to the harsh condition they face simultaneously, Blacks keep a desire to change into Whites.

If he is overwhelmed to such a degree by the wish to be white, it is because he lives in a society that makes his inferiority complex possible, in a society that derives its stability from the perpetuation of this complex, in a society that proclaims the superiority of one race; to the identical degree to which that society creates difficulties for him, he will find himself thrust into a neurotic situation (Fanon, 2008: 74).

The attempt to change Whites is merely illusion since the colonized expect Blacks to remain Blacks. They hamper and bar Blacks from all participation that is decently suitable to equal Blacks with them. To put it simple, Whites take advantage of the racial prejudice as an apparatus to make Blacks unconscious of their inferiority. According to Fanon (2008: 116), "the Negro is unaware of it as long as his existence is limited to his own environment; but the first encounter with a white man oppresses him with the whole weight of his blackness." 'It" refers to the myth that has been created by Whites make Blacks believe that their inferiority comes from the origin. 
Blacks do not have the time to realize. Instead, they are led to face a new element of the apparatus which makes them more inferior, named guilt (Fanon, 2008: 116). Blacks are pushed to feel guilty unconsciously because their origin is determined as sinful. They bring all the characteristics of lower emotions and attitudes. They are made to believe that as Blacks they deserve to accept severe treatments because it is in line with their fundamental essence.

\section{BLACK WOMEN'S RURAL LIFE IN THE SOUTHERN SOCIETY}

The rural South plantation was an exotic land with a long history of slavery. It was different from the modern North industry. The distinctiveness not only lay in terms of geographical and economical ideas, but also social. The relation between people in the South was more communal. However, this communal relation had a hidden tension because Southerners adopted segregation as essential element in their way of life. Therefore, most Blacks and Whites in the South lived under certain rules manifested in a regulation named the Jim Crow Laws.

The lives of the Blacks in the South are daily related to servant or household works. Many Black women worked as housemaids in white men's houses. They took care of the house, children, and cooked for the owners. These women sometimes also were considered as the objects of white men's sexual pleasure. Slavery has provided a possible sexual relation for Southern white men. It was provided everywhere a class of women who were theirs for the buying. The relic of slavery that has been banned could not erode in a sudden. Some practices were still maintained, including using black women to fulfill white men's sexual pleasure.

However in the practice, white people tended to override a slight taint of African ancestry (Williamson, 1993: 384). For instance, if the result of the relationship of different races was a mixed blood child, the mixed blood child as the result of the relationship between men and women from different races would not get a complete acceptance since there was no marriage admitted if the thing happened.

\section{TRAUMA IN NANCY'S CHARACTER}

The main problem needs to be examined in Faulkner's "That Evening Sun" is how Nancy, the Black woman servant, deals with her crippling fear which results in a trauma caused by the fact that she is pregnant with a white man's child. She 
starts to hallucinate that her husband is hiding in the ditch, waiting to kill her when she comes from work. To analyze Nancy's fear which accumulates and becomes a trauma, additional information related to the lives of the Blacks in the South is required to explain the main cause of the fear which is socially connected with the rural life in the South. The analysis also highlights Faulkner's natural ability to emphasize the grievous condition of Nancy by comparing the fear experienced by Blacks and Whites in the story. Since it is not only Nancy as the representative of the inferior group who faced dread, but also some white characters in the story as the superior group.. The discussion will divide the analysis into two parts. The first is on how the fear starts to occupy Nancy and how the fear accumulates into a trauma. The second focuses on the fear experienced by Blacks and Whites in the story. Some facts regarding the lives of the Blacks in the Southern part of the United States are provided as information to aid the process of analysis.

The story itself is based on a third person narration. Faulkner skillfully crafts the short story employing the third person point of view who involves in the circumstance. Faulkner uses Quentin Compson's perspectives as a twenty fouryear-old man who narrates back the story of his childhood and a nine-year-old boy who naively responds his surroundings. The point of view at the beginning shows the skeptical tone of Quentin responding to the altering atmosphere in Jefferson. This is the tone of an adult. The tone starts to change when the story involves the young Quentin and his siblings. The story is told naively in a sequence of events based on the point of view of a young boy. The altering tones are sufficient to emphasize the social gap that existed between Nancy and the children and also to highlights Quentin's attitude towards his hometown, Jefferson. The main issue that becomes the focus of the narrator is the life of a black servant named Nancy. Thus, Quentin as the master told the life of his servant dealing with her fear of her husband who wants to kill her.

\section{Nancy's Fear Leading into Trauma}

The story begins with Quentin who conveys the current situation of Jefferson. He finds it unpleasant since many things have changed. He tells with disdain how modernity replaces the old harmony in the past. Faulkner employs adjectives such as "bloated", "ghostly", "bloodless", and "irritable" to strengthen Quentin's dislike. Later on, he portrays the past as a sequence of very compelling daily lives of Black servants who used to fill the atmosphere of mornings in Jefferson. As a Southerner, Quentin more favors the old custom fifteen years ago 
rather than the present time. The reminiscence of the past looks more harmonious in the eyes of Southerners although the harmony of the rural life is tragically represented by the unequal lives of Whites as masters and Blacks as their servants. These unequal treatments are also the reasons of Nancy's suffering which leads to her fear and accumulates into a trauma.

Fifteen years ago was the time when a nine-year-old Quentin and his siblings, Caddy and Jason, spent most of their days with their housemaid, Nancy. Nancy was portrayed as an unstable person since the very beginning of the story. The young Quentin saw her being dragged to the jail and locked there. The cause for her imprisonment was due to her accuse to Mr. Stovall, the cashier in the local bank and a deacon in the Baptist church, of not paying her satisfyingly for the sexual service she gave to him. Before going to the jail, Mr. Stovall got enough time to beat Nancy and made her lose her teeth.

The Southern society was accustomed with severe treatments for Blacks. Thus, Mr. Stovall's savage treatment to Nancy did not make him being processed to the trial. On the contrary, Nancy was accused as being drunkard and also a cocaine user by behaving as such, "He said that it was cocaine and not whisky, because no nigger would try to commit suicide unless he was full of cocaine, because a nigger full of cocaine wasn't a nigger any longer" (Faulkner, 1950: 291). At least that is what a little Quentin heard from his surroundings when Nancy attempted to commit suicide. The cause was Nancy found herself pregnant with a white man's child and it caused outrage of her husband, Jesus. Nancy then tried to commit suicide in the jail but the jailer soon found her and beaten then whipped her. For Southern society, it was common to have black women being pregnant with white man's child since colonial apparatus was not only making the colonized superior but also took advantage of them. The severe punishment was also common for black women since their inferiority complex unconsciously pressured them to regard the unpleasant treatment as a part of their unlucky life as Blacks.

As for Jesus, Nancy's husband, Quentin as a kid described him as threatening. It was clearly depicted by Quentin's explanation of his countenance by saying "his razor scar on his black face like a piece of dirty string" (Faulkner, 1950: 292). Faulkner employs a white Southerner's point of view to point out the racial prejudice through Quentin's eyes. Quentin valued Jesus' character by simply looking at his physical appearance. The words chosen by Quentin shows his disrespect towards Jesus. 
As a man, Jesus felt that his pride was ruined by a white man because his wife was pregnant with a white man's child yet he could do nothing since his position as a black man gave him no power to strike back or even expressed his anger towards them. Thus, he was merely able to accuse his wound by saying:

"I can't hang around white man's kitchen," Jesus said. "But white man can hang around mine. White man can come in my house, but I can't stop him. When white man want to come in my house, I ain't got no house. I can't stop him, but he can't kick me outen it. He can't do that" (Faulkner, 1950: 292).

The vexation was his expression of his disability to take revenge over what happened to his life. Jesus was the example of a miserable black man whose wife became the object of white man's sexual desire. Although Nancy was told giving sexual service willingly for money, the fact that Nancy was pregnant with other's man child was a loss to his life and pride. Some of the Blacks in the South held on religion as their last support to face the harsh lives. The Southerners were known as religious society, including Blacks. There were some famous black congregations back in the past. They had their own church because they could not worship together with the Whites in the same chamber. Started from this fact, Jesus' misery could be said as the result of his shame for not being able to take care of his wife.

Although this religious community seemed really strict to morality, actually it did not seem like what it was, especially for the white Southerners. Many white men kept black women slaves to fulfill their sexual pressure. That was back in the time when slavery was still legal. Slavery was already banned the time when the story took place, but the practice could not completely erode from the society. That was the relic that somehow was still maintained with a different name and the society still considered it as customary. This miscegenation produced mixed children. Southern society who legalized miscegenation were unwilling and rejected to accept the mixed children as the result of miscegenation. Mixed children did not get legal acceptance in the eyes of the Whites. Blacks also refused to accept them since they did not completely belong to their group. Their status was blurred because they embraced two different worlds, but somehow they also did not belong to both of them.

Because Jesus was limited to express his anger and disappointment, Nancy was the only living thing to whom he could pour his disappointment. As the aftermath, Nancy's fear started to emerge as she begins to continually hallucinate that her husband was going to kill her. Nancy began to dream that Jesus would 
come and kill her alive on the pathway to her cabin although when the time Nancy started to be occupied by her delusion as the result of her tangible fear, Jesus already left the town and abandoned her. Nancy's fear was possibly resulted from Jesus' constant threat to her after she was known having an affair with a white man. Nancy said that previously Jesus was a good man. "Jesus always been good to me," Nancy said. "Whenever he had two dollars, one of them was mine" (Faulkner, 1950: 294). He used to accompany and wait for Nancy when she worked at Compson's family. The change of his behavior was presumably due to Nancy's disloyalty to him. He changed into a rude person until finally Mr. Compson told him to stay away from his house. It was likely because he often behaved violently to Nancy when he knew the pregnancy so Mr. Compson prevented him to come near his house.

However, his continual violence to Nancy resulted in Nancy's fear which then turned greater as her belly gradually swelled although at that time Jesus was already gone. Nancy was dreadful that Jesus would come in a sudden and hurt her. At the beginning, Nancy could still manage her fear. She was conscious that her husband already left although she was still afraid. She even told the children and Mr. Compson that she was no longer living with him, "Jesus is gone," I said. Nancy told us how one morning she woke up and Jesus was gone. "He quit me," Nancy said. "Done gone to Memphis, I reckon. Dodging them city po-lice for a while, I reckon" (Faulkner, 1950: 293). But as time went by, she began to hallucinate that Jesus was already in town. When she stayed in the Compson's house, at night she hollered and produced peculiar sound. She attempted to attract the members of the house to accompany her at night. Mr. Compson decided to move Nancy's pallet to the children's room.

Her delusion grew worse as she imagined that Jesus would kill her anytime she was left alone by her companion. She thought that Jesus was waiting for him in the ditch and when she passed by, he would kill her alive. This dreadful thought made her to take the children in her cabin to accompany her. She tried to attract the children as much as she could to make the children stay. At that time, her consciousness started to lose. When she narrated a story to draw attention of the children who started to whine, her mind was beginning to be occupied by her fear as she said, "And so this here queen come walking up to the ditch, where that bad man was hiding. She was walking up to the ditch, and she say, 'If I can just get past this here ditch,' was what she say ..." (Faulkner, 1950: 302). Here, it is clear that 
Nancy's consciousness started to lose and her unconsciousness replaced it. Her unconsciousness was filled with Jesus' attempt to kill her from the ditch as now the accumulation of her fear turned into a trauma. Violent treatment that previously Jesus ever did to him gradually came to lose her sanity. She could not sense her surroundings properly. Thus, she could not feel when her hand was burnt, "Nancy built up the fire, "Look at Nancy putting her hands in the fire," Caddy said."What's the matter with you, Nancy?" (Faulkner, 1950: 304).

When she heard peculiar sound outside, her body reacted by producing tears. Although she denied that she was crying, her crippling fear which now had turned into trauma made her believe as if Jesus was outside and he was stepping closer to kill her. Her behavior was her surrender to herself. When she knew that it was Mr. Compson picking up his children, her trauma did not cease, in fact, it grew greater because she said that Jesus already came to the house, looking for her. "I got the sign," Nancy said."What sign?" "I got it. It was on the table when I come in. It was a hogbone, with blood meat still on it, laying by the lamp. He's out there. When yawl walked out that door, I gone" (Faulkner, 1950: 307). She thought that Jesus came bringing a hog bone as a threat to kill her. She absolutely believed that when Mr. Compson and the children went, Jesus would came and immediately killed her. For this, she could not escape anymore. Her trauma was so acute. Therefore, when Mr. Compson and the children left her, she let the door remain open because her trauma dragged her to believe that she would die that night as soon as the Compsons left her.

Nancy's surrender is somehow her acceptance of her unfortunate life as a black woman. Many times she mumbled that her ultimate death was just her fate as a black woman which she could not change. She thought that she did no mistake since it was the society who wanted her to do it, "I just done got tired," she said. "I just a nigger. It ain't no fault of mine" (Faulkner, 1950: 309). The statement referred to her incapability to fight what had been decided to her. This incapability relates to her weak position as a black and as a woman. She did not have enough power to gain respect and fairness in her society. She demanded equality but she could not own it because of her skin color.

Regarding her fear, the Compson's family respond towards Nancy's fear shows that they had no interest upon it. Mr. Compson as Nancy's master considers Nancy's fear as merely nonsense and reacts unsatisfactorily such as "There's nothing for you to be afraid of now" (Faulkner, 1950: 295). The same constant 
answer to Nancy proves that the Whites are never interested in the lives of the Blacks. They merely considered them as objects and did not want to involve in their lives. It was different from the reaction shown by Dilsey, another black servant working for Compson's family, when she knew that Nancy began to collapse due to her own fear. Dilsey took care of Nancy. She made sure that Nancy received complete attention and offered to accompany her going back to her cabin.

\section{Fear Felt by Blacks and Whites in Jefferson}

Faulkner used his aptitude to contrast the fear felt by the Blacks and Whites in the story in order to point out that the effect and cause of fear for Blacks was greater compared to the Whites. Fear in Jefferson is not solely owned by Blacks. Whites also experienced the same feeling although the kind, cause, and degree are different from that of the Blacks. Mrs. Compson had fear. Mr. Stovall had fear. Even the children also had fear.

Mrs. Compson felt afraid of her solitude for her husband and children used to leave her to accompany Nancy going home. The feeling of jealousy was also slightly inserted in the fear since Nancy was also a woman. Moreover, she was pregnant with a white man's child. As a woman whose husband was a master of the black woman whom he always accompanied, Mrs. Compson was afraid that her husband would take advantage of Nancy. Therefore, there were some occasions in the story when Mrs. Compson attempted to prevent her husband from accompanying Nancy, "You'll leave me alone, to take Nancy home? Mother said. "Is her safety more precious to you than mine?" (Faulkner, 1950: 293). The expression was a mix of anger, jealousy, and fear. Mrs. Compson finally decided to permanently stop her husband and children from taking her home by saying, "How much longer this going to go on? I to be left alone in this big house while you take home a frightened Negro?"(Faulkner, 1950: 296). Mrs. Compson's last try was a reflection of her absolute concern to save her family from shame that might happen. Therefore, although she knew that Nancy was completely occupied by her dread, she chose not to take any slightest care towards her life since for a respectable family like hers, dealing with the lives of Blacks means nothing.

As a white man, Mr. Stovall was also petrified when Nancy started to fill the town's street by her accuse to him of not paying her adequate amount of money after she gave him sexual service. His pride as a respectable man was at stake for a 
miscegenation scandal and also that he had not paid her the sufficient money for the service. It was not something uncommon for white men in the South to take advantage of black women, yet this deed was not something that anyone could bear if it was publicly announced, particularly if it was declared by the black woman as the victim. His anger which was combined by his shame led him to punish Nancy with his stringent and brutal conduct

Mr. Stovall knocked her down, but she kept on saying, 'When you going to pay me, white man? It's been three times now since" until Mr. Stovall kicked her in the mouth with his heel and the marshal caught Mr. Stovall back, and Nancy lying in the street, laughing. She turned her head and spat out some blood and teeth and said, "It's been three times now since he paid me a cent" (Faulkner, 1950: 291).

Mr. Stovall defeated Nancy savagely to express his emotion and fear since Mr. Stovall's respectable positions as a cashier in the bank and a deacon in the Baptist church were harmed by Nancy's statement. His demeanor was the expression of anger and fear. He was angry because Nancy dared to accuse him publicly. He was also afraid that society would see him differently. However, society regarded that Nancy deserved to accept the punishment from Mr. Stovall for Jefferson society only did minor action to prevent Mr. Stovall from knocking her down. After that, Nancy was dragged atrociously to the jail.

After considering the profession of Mr. Stovall and society's response towards his misdeed, it might be said there was hypocrisy in the Southern society. Different from their brothers in the North, the Southern population was highly regarded as religious community. However. Mr. Stovall's respectable profession as a cashier did not hamper him from doing amorality. Moreover, being a Baptist Church deacon also did not prevent him from behaving atrociously towards other human beings while the teaching of religion ordered its members to behave equally.

It would be completely contrasting if the victim of the abuse was a white woman and the doer was a black man. The black man would be for sure accepting more severe punishment from the society than the white woman. It was very likely that the black man would be lynched and the case never went into trial. This is how racial prejudice as an ideology was implemented in the South. Racial prejudice was the base of all conducts if it involved Blacks and Whites. Whites, no matter they were right or wrong, women or men, got protection while Blacks must be on the 
group whose rights were profoundly disrespected. The collapse of values, principles, and norms, either in the relationship between human or the religion conduct was the characteristics of society with racial prejudices.

The third party who also experienced fear was the children. Caddy was the bravest among them. Jason was considered as the coward because he was the youngest. Quentin took a neutral position as the eldest. Same with Nancy, they were also afraid of the darkness. They were suspecting that the ditch on the night was the most dangerous place for there could be anything that emerged at anytime. They teased each other about who was the most afraid among them. It was playful interaction because everybody knows that there was nothing within the ditch except honeysuckle. Faulkner used the naïve children who playfully teased each other about who was the most afraid of the darkness to contrast to the real fear of Nancy over her husband, Jesus. In other words, the comparison was also used to point out how the fear that was felt by Blacks was more real and petrifying compared to the fear experienced by the Whites.

In some parts of the story, Faulkner made the children and Nancy experiences fear at the same time.

"I'm not afraid to go," Caddy said. "Jason is the one that's afraid. He'll tell."

"I'm not," Jason said.

"Yes, you are," Caddy said. "You'll tell."

"I won't tell," Jason said. "I'm not afraid." (Faulkner, 1950: 301)

They all walked together to accompany Nancy going back to her house. Caddy and Jason started to tease each other as soon as they entered the darkness. The playful teasing between the children caused no fearful impression to the readers. Instead, it sounded funny and naïve. It was quite contrasting with the fear experienced by Nancy.

"What are you talking so loud for, Nancy?" Caddy said.

"Who; me?" Nancy said. "Listen at Quentin and Caddy and Jason saying I'm talking loud."

"You talk like there was five of us here," Caddy said. "You talk like father was here too."

"Who; me talking loud, Mr Jason?" Nancy said.

"Nancy called Jason 'Mister,"'Caddy said.

"Listen how Caddy and Quentin and Jason talk," Nancy said.

"We're not talking loud," Caddy said. "You're the one that's talking like father" 


\author{
"Hush," Nancy said; "hush, Mr Jason." \\ "Nancy called Jason 'Mister' aguh" (Faulkner, 1950: 301)
}

Nancy acted as if there was Mr. Compson among them. The first name of Mr. Compson was the same with Jason. Therefore, the children considered it as a funny thing when they thought that Jason was called "Mister". The truth was Nancy pretended that there was a white man among them with an assumption that Jesus would not be brave to attack them. The constant fear occupied Nancy so bad which made her talk so loud to prove that Mr. Compson was with them. From that dialogue, it was clear how Nancy's fear was serious while the children, as soon as they found the new thing to care about, they forgot their fear about darkness.

\title{
CONCLUSIONS
}

Nancy's case reveals that the racial prejudices that happen in colonial society can lead one of its members into a trauma. As a representative of a marginalized member of society due to her skin color, Nancy receives inappropriate treatments from her surroundings. Her pregnancy with a white man makes her have to endure harsh behaviors from her husband, Jesus. Regarding his harshness, Jesus makes Nancy as an object of his anger and disappointment because he thinks that his life is miserably fooled by Whites. Jesus feels incapable of fighting back what the Whites have done to her. It results in Nancy's fear of him which gradually transforms into an acute trauma. Her consciousness fades as she starts to hallucinate Jesus' presence who wants to kill her. The accumulation of her fear is also encouraged by the apathetic responds of her surroundings, which mostly consist of Whites, over her crippling fear.

Faulkner's technique to contrast the fear experienced by Blacks and Whites in "That Evening Sun" is effective to show that Blacks receive more serious and acute level of fear compared to that of Whites. Faulkner also shows how Whites deal with the fear of Blacks. Whites tend to ignore and prevent themselves to involve in the problem faced by Blacks. 


\section{REFERENCES}

Ayers, E.L. 1998. Southern Crossing: A History of the American South, 18771906. New York and Oxford: Oxford University Press.

Creswell, J. W. 2009. Research Design Qualitative, Quantitative, and Mix Methods Approaches ( $3^{\text {rd }}$ Ed.). London: Sage Publications.

Fanon, F. 2008. Black Skin, White Masks. London: Pluto Press.

Faulkner, W. 1950. Collected Stories of William Faulkner. New York: Random House.

Kaplan, E.A. 1999. "Fanon, Trauma, and Cinema" in A. C. Alessandrini (Eds.), Frantz Fanon: Critical Perspectives. New York: Routledge.

Lowe, J. 2005. Bridging Sothern Culture. Louisiana: Louisiana State University Press.

Matthews, J. T. 2009. William Faulkner: Seeing Through the South. West Sussex: Wiley-Blackwell.

McNeese, T. 2010. The Civil War Era: 1851-1865. New York: Chelsea House.

McPherson, J.M .1988. Battle Cry of Freedom: The Civil War Era. New York: Oxford University Press.

Smith, J.D. 2002. Managing White Supremacy. London: The University of North Carolina Press.

Williamson, J. 1993. William Faulkner and Southern History. New York: Oxford University Press. 